\title{
Myšlení budoucnosti a potřebnost transformativního přístupu ve vzdělávání
}

\author{
Laura Henderson, Jana Dlouhá
}

Envigogika 16 (1) - Recenzované články/Reviewed articles

Published/ Publikováno 14. 10. 2021

DOI: https://dx.doi.org/10.14712/18023061.621

\begin{abstract}
Abstrakt
Článek se věnuje potřebě transformovat vzdělávání, aby se podpořila osobní angažovanost žáků potřebná k nastartování společenských změn $\mathrm{k}$ udržitelné budoucnosti.

Autoři se zabývají perspektivou budoucnosti ve školním vzdělávání - ukazují, jak bychom mohli podpořit studenty při překonávání apokalyptických vizí budoucnosti, a/nebo omezit spoléhání se na technokratická řešení, která je zbavují odpovědnosti, protože neposkytují žádný prostor pro představu o tom, jak je možné aktivně přispívat a spolupracovat na utváření budoucnosti. Zkoumáme způsoby, jak žáci mohou kriticky zpochybnit dogma, že "neexistuje alternativa" $\mathrm{k}$ současnému dominantnímu, sebezničujícímu systému, a poskytujeme přehled pedagogických přístupů, které podporují žáky v kritickém hodnocení vlastních hodnot a zapojují jejich představivost tak, že vytváŕí alternativní vize budoucnosti. Článek nabízí přehled o zdrojích, které poskytují inspirativní př́iklady k podnícení naší představivosti týkající se toho, co možné a co se již děje. Představuje aktivity, které jednotlivcům a pedagogům zprostředkují porozumění „imaginace" budoucnosti, a podpoří jejich reflexi sebe sama jakožto činitele změny.
\end{abstract}

\section{Klíčová slova}

Vzdělávání pro udržitelný rozvoj; transformace; myšlení budoucnosti; představivost

\begin{abstract}
The article addresses the need to transform education to ensure pupils' personal commitment required to fuel social transformation towards a sustainable future.

The authors explore how the future is addressed in school education, and how we might support students in going beyond imagining apocalyptic visions of the future, or technocratic solutions, both of which are disempowering as they provide no space for imagining and actively contributing to co-creating the future. We explore ways that pupils can critically question the dogma that "there is no alternative" to the current dominant, self-destructive system, and provide an overview of pedagogical approaches which support pupils to critically evaluate their values and engage their imaginations to create alternative visions of the future. The article offers a collection of resources that provides inspirational examples to ignite our imagination about what can and is already being done, and reflective activities to support individuals and educators to explore how and why we imagine the future with a view to encouraging self-perception as an agent of change.
\end{abstract}

\section{Key words}

Education for sustainable development; transformation; futures thinking; imagination 


\section{O co jde?}

V současném světě se nepř́znivé procesy, jako je klimatická krize a sociální nespravedlnost, nejen zrychlují, ale také prohlubují. Šíření stále rostoucího množství dostupných informací o těchto problémech ale nemá zamýšlený dopad, protože samotné poznatky nevybízejí k akci, a tudíž ani ke změně (Shove, 2010). Dnes je již jasné, že k nápravě škod na životním prostředí a $\mathrm{k}$ celkovému zlepšení potřebujeme poměrně zásadní společenskou změnu, a s tím souvisí i nutnost změny chování každého jednotlivce. Procesy změn však nemohou být nastartovány pouhým učením faktů (Sterling 2010) - "behaviorální" změny totiž nejsou výsledkem kauzálních, lineárních procesů, plně ovlivňovaných racionálními podněty; naopak do hry vstupují např́klad emoce a vliv celkového prostředí ve společnosti. $\mathrm{K}$ potřebné společenské změně tak nedochází proto, že jsme většinou plně zakotveni ve svých zvyklostech a nedovedeme si představit alternativy současného ekonomického i sociálního systému: „Pokud má systém pevnou kontrolu, již nepotřebuje dưvěru: funguje na základě rutiny... a absence predstavivosti" (Duncombe, 2012). Abychom byli schopni tuto situaci zlepšit, musíme využít nejen vědecké poznání, zapojit politiku, ale pracovat také s dalšími nástroji pro rozvoj osobnosti v rovině emocionální a sociální - např́íklad pomocí umění či zapojování do občanské společnosti. To vše pak Ize využít ve vzdělání, které by dokázalo přispívat nejen k udržení současného stavu, ale i k jeho nápravě či zlepšování (Reed, 2007). Takové vzdělání, které dětem/žákům/studentům dovolí si plně uvědomit situaci, ve které se v dané chvíli nacházejí; otevře jim možnost rozmyslet si, $v$ čem by se mohla či měla změnit; a rozvine $v$ nich znalosti, kompetence, nebo jim poskytne jiné nástroje, s jejichž pomocí dokáží zahájit změny, které by ovlivnily jejich bezprostřední život či budoucí stav prostředí a společnosti jako takové, nazýváme transformativním (viz Dlouhá et al., 2021).

\section{Myšlení budoucnosti}

Abychom dokázali přemýšlet o možném zlepšení či „nápravě" světa, musíme zvolit úhel pohledu, v němž se podobné úvahy osvědčí, umožní nám aktivně se bránit nepříznivým okolnostem, nebo povzbudí vytváření pozitivních vizí. To vše jsou důvody, abychom si osvojili perspektivu budoucnosti - teprve poté, co ji budeme zvažovat $v$ myšlenkách, budeme schopni tuto budoucnost také ovlivňovat $v$ praxi. Naše představy o budoucnosti jsou dnes ovšem často "kolonizovány" soubory zažitých nebo účelově vytvářených představ - především:

- (víceméně ideologicky založenými) príběhy o tom, že „neexistuje žádná alternativa” ( $v$ souladu s tvrzením Thatcherové). Volba, která před námi stojí: moderní globální svět expandujícího pokroku (volný trh, méně vládní kontroly a energické technologické inovace), nebo na druhém konci spektra neúčast na globalizaci - regrese a zaostávání. To vytváří iluzi, že alternativy jsou možné pouze $v$ tomto spektru, a uzavírá debatu o tom, co jiného, než toto spektrum existuje; výjimkou jsou jen tvrzení politiků, kteří využívají potřebu uklidnit občany $v$ této náročné době a nabídnout jim nový narativ: návrat ke "starým dobrým časům" (viz Trumpův Make America Great Again nebo psychologické př́činy brexitu). Tedy narativ, který je zcela odtržený od ekologických limitů planety a tlaků reality (Latour, 2018),

- mediálním zobrazením dystopie, tragických obrazů světa, které nahrávají použití různých nástrojů moci či kontroly,

- technologickými možnostmi, jež se zdají neomezené a mohou vše vyřešit. 
Tyto představy o budoucnosti (formované vnějšími podněty) jsou založeny na jisté osudovosti a rozhodně nás neprovokují $\mathrm{k}$ tomu, abychom je přehodnotili a přizpůsobili vlastním hodnotám a cílům. Právě proto je tak důležité rozvíjet tzv. myšlení budoucnosti, které provokuje $\mathrm{k}$ vytvoření představ vlastních, jež mohou těžit $z$ vlastních zkušeností a formovat hodnoty pro další postup. Tento přístup je důležitý právě ve vzdělávání - kde je možné pěstovat schopnost nahlížet budoucnost kriticky, a vést $k$ uvědomění, že současný stav Ize změnit, pokud není vyhovující, tedy jej zlepšit například s cílem spravedlivějšího uspořádání společnosti. Pod tímto úhlem pohledu se jeví současné sociální zvyklosti jako pomíjivé, závislé na stavu společnosti; a tato perspektiva může posilovat sebevědomí mladých lidí a jejich schopnost věci ovlivňovat. Jde o kritickou perspektivu, která je výrazně emancipační (Ahlqvist, Rhisiart, 2015) tím, že dokáže osvobodit od předsudků, které by mohly bránit svobodnému rozvoji nejen jednotlivce, ale i celé společnosti.

Zde je třeba poznamenat, že věda se na budoucnost může dívat i jinak, základy výzkumu mohou být (kromě kritického hlediska zmíněného výše) také empirické a interpretační. Každý z těchto př́stupů má jiné předpoklady o skutečnosti, o povaze budoucnosti a roli jednotlivce $v$ jejím formování. Empirická tradice se zabývá možnostmi předpovídání budoucnosti, $v$ interpretační jde o vytváření vzájemného porozumění. To souvisí s tím, že věda zde může plnit praktické úkoly: pomáhá predikovat budoucnost (empirický přistup) nebo srovnávat různé představy o ní (komparace je základem interpretačního př́stupu) - obojí je důležité např́klad z hlediska tvorby politik. Ovšem kritický pohled, který formuje myšlení budoucnosti $v$ našem pojetí nejvíce, se proti těmto dvěma vymezuje - zde jde naopak o to, nějakým způsobem „zpochybnit" všechny platné koncepce budoucnosti a přehodnotit definice souvisejících pojmů.

Myšlení budoucnosti, které by se mohlo prosadit ve vzdělávání obecně, tak nepracuje s fakty, ale s představivostí. Právě schopnost si představit alternativní vize, a ty potom zvažovat $z$ hlediska rizik a přínosů, je východiskem všech procesů změny. Jaké jsou však předpoklady pro to, aby se naše představivost rozvíjela? Potřebujeme k tomu: nestrukturovaný čas; svobodu tvořit bez předem definovaných očekávání a beze strachu z hodnocení; pocit bezpečí a nepř́tomnost stresu. Život dnešních dětí je ale často neposkytuje: nepříznivé životní podmínky, a především tlak ze strany školy někdy způsobují, že mezi dětmi narůstá úzkost, která má vážný dopad na fungování amygdaly, oblasti mozku, kde sídlí pamět́ a schopnost vytvářet nové nápady a sny o budoucnosti (Van der Kolk, 2015). Děti čím dál méně věř́, že mohou ovlivňovat své životy (Gray, 2011; Twenge et al., 2004), a většinou ani nemají dostatek času na aktivity zapojující představivost (Hopkins, 2019). Ve tř́dách se snižuje úroveň zvídavosti (tamtéž) a od 90. let se ukazuje, že úroveň kreativního myšlení klesá (Kim, 2011) - v období posledních 30-ti let současně narůstá př́stup $k$ technologiím a zároveň se ve vzdělávání více klade důraz na standardizaci a testování. Ti, kdo by kreativní přístupy podporovat mohli a chtěli, kromě toho naráží na skutečnost, že ve škole pro rozvíjení představivosti nejsou př́liš dobré podmínky. Kreativita jsou učitelé ochotni přijmout, pokud slouží k podpoře kompetencí, které jsou již jako vzdělávací cíle stanoveny. Samotný rozvoj představivosti ale za hodnotný cíl považován není. Naše osnovy pořád ještě $v$ mnoha ohledech vycházejí ze stavu společnosti před 100 lety, kdy byla fakta nezbytná pro ekonomický rozvoj průmyslové výroby, a pojem "inovace", zcela nový nápad či zlepšení, které může přinést kdokoli, nebyl znám.

Jak dokládá výzkum provedený na českých školách v rámci programu Jeden svět Člověka $v$ tísni (JSNS), kde byly předmětem zájmu motivace a bariéry podílet se na řešení společenských problémů, více než polovina středoškoláků tak má obavy z budoucnosti a jen čtvrtina žáků věrí, že problémy může ovlivnit vlastní aktivitou. $S$ tím je spojena dynamika sociální nerovnosti, protože pocit, že mohou ovlivnit řešení, je častější u žáků z gymnázií a z rodin s vysokou životní úrovní (JSNS, 2020). 


\section{Principy pro využití ve vzdělávání}

Výzkum Gidley et al (2004), který se zabýval rolí budoucnosti ve vzdělávání, popisuje typologii budoucností, jak se její atributy objevují ve školních osnovách: v nich je budoucnost vyjádřena jako pravděpodobná, možná, preferovaná (upřednostňovaná) a perspektivní (výhledová). Níže uvedená tabulka poskytuje stručný popis a analýzu principů, cílů a výzkumných metod každého př́stupu.

\begin{tabular}{|c|c|c|c|c|}
\hline Budoucnost & Pravděpodobná & Možná & $\begin{array}{c}\text { Upřednostňo- } \\
\text { vaná }\end{array}$ & Výhledová \\
\hline $\begin{array}{l}\text { Popis prin- } \\
\text { cipů a vý- } \\
\text { chodisek }\end{array}$ & Analýza trendů & $\begin{array}{c}\text { Nápadité, kre- } \\
\text { ativní }\end{array}$ & $\begin{array}{l}\text { Hodnotové za- } \\
\text { kotvení, kritické }\end{array}$ & $\begin{array}{l}\text { Ochota jednat, } \\
\text { soběstačnost, } \\
\text { zmocnění }\end{array}$ \\
\hline $\begin{array}{l}\text { Určující pa- } \\
\text { radigmata }\end{array}$ & $\begin{array}{l}\text { Pozitivistické, em- } \\
\text { pirické, analytické }\end{array}$ & $\begin{array}{l}\text { Konstruktivis- } \\
\text { tické, inter- } \\
\text { pretační, her- } \\
\text { meneutické }\end{array}$ & $\begin{array}{l}\text { Kritické, eman- } \\
\text { cipační }\end{array}$ & $\begin{array}{l}\text { Posun paradig- } \\
\text { matu, transfor- } \\
\text { mační, aktivis- } \\
\text { tické }\end{array}$ \\
\hline Cíl & $\begin{array}{c}\text { Zobecnění, extra- } \\
\text { polace }\end{array}$ & $\begin{array}{l}\text { Otevírání al- } \\
\text { ternativních } \\
\text { možností }\end{array}$ & $\begin{array}{l}\text { Kritické uvědo- } \\
\text { mění, dekon- } \\
\text { strukce }\end{array}$ & $\begin{array}{c}\text { Zmocnění, } \\
\text { změna, trans- } \\
\text { formace }\end{array}$ \\
\hline $\begin{array}{l}\text { Výzkumné } \\
\text { metody }\end{array}$ & $\begin{array}{l}\text { Kvantitativní, před- } \\
\text { povídání, prů- } \\
\text { zkumy, vývojové } \\
\text { scénáře }\end{array}$ & $\begin{array}{l}\text { Kvalitativní, } \\
\text { dialogy, kola- } \\
\text { borativní, kre- } \\
\text { ativní vize }\end{array}$ & $\begin{array}{l}\text { Analýza textu, } \\
\text { kritika médií, } \\
\text { kulturní arte- } \\
\text { fakty, tvorba } \\
\text { vizí }\end{array}$ & $\begin{array}{l}\text { Celkovost, } \\
\text { tvorba vizí, } \\
\text { akční plánování, } \\
\text { akční výzkum }\end{array}$ \\
\hline
\end{tabular}

Tabulka 1: Typologie budoucností, jak se objevují v kurikulech (dle Gidley at al 2004)

Jak vidíme v tabulce č. 1, tyto formy vnímání budoucnosti vyžadují od žáků značně vysokou úroveň reflexe hodnot a kritického myšlení; vrcholem je transformativní přístup k výhledové budoucnosti. Tento proces vychází z angažovanosti, zmocnění (empowermentu) a z akčního zapojení žáků, což vyžaduje různé mody vědění. K prosazování tohoto přístupu v praxi jsou využity rozmanité metody jako je vizualizace, akční bádání a plánování akcí.

\section{Nástroje výuky budoucnosti}

Představivost je nezbytným základem myšlení budoucnosti: neexistují žádná budoucí fakta. Všechny „informace", které máme o budoucnosti, pocházejí z naší zkušenosti s minulostí, našeho pozorování současnosti a schopnosti ptát se "Co kdyby?", tedy pracovat s nápady, představami a hodnotami, které chceme, aby se projevily.

Práce Wendy Shultz (in Gidley et.al 2004, str.24) v oblasti „zvládání budoucnosti" má zásadní význam kromě jiného i ve vzdělávacích programech. Tato autorka jako základní schopnost $v$ této souvislosti definuje "dovednost a potěšení z kreativního, kritického a konstruktivního využití výhradně imaginativních spekulací".

Shultz dále hovoří o pěti základních fázích a příslušných nástrojích zvládání budoucnosti, které jsou základem každé z nich: 
1. Zjištování a monitorování změn - tato schopnost se nejlépe rozvíjí analýzou vznikajících problémů (je také známa pod pojmem skenování prostředí).

2. Kritický pohled na důsledky změn, který se opírá o nástroj známý jako analýza dopadů.

3. Představy alternativních možností budoucnosti, což zahrnuje incasting (deduktivní předpovídání alternativ budoucnosti).

4. Schopnost představovat si preferované verze budoucnosti nebo ideály, a to na základě vytvoření vize - $v$ rámci imaginativního, idealisticky založeného nebo normativního procesu, který pomáhá lidem výslovně formulovat jejich preferovanou budoucnost.

5. Fáze plánování a implementace / dosažení zamýšleného stavu - zahrnuje zpětnou analýzu (backcasting), jejímž cílem je překlenout propast mezi událostmi v možné budoucnosti (nebo ještě častěji v té, jež je preferována) a v budoucnosti, kterou pokládáme za rozšířenou prítomnost.

Konečně, po dokončení pěti fází, se musíme vrátit na začátek, k identifikaci, kontrole a monitorování všech změn, ke kterým došlo. Ačkoli práce Shultzové většinou míríla na dospělé jedince $v$ korporátním sektoru, koncept zvládání budoucnosti a metody použité $\mathrm{k}$ jejímu nácviku by mohly být stejně použity ve školním prostředí.

\section{Jak zavádět hledisko budoucnosti do vzdělávací praxe?}

Ačkoli všechny výše zmíněné úhly pohledu na budoucnost mohou vzdělání obohatit, my zde z této rozmanitosti vybíráme ty, které by mohly formovat tzv. perspektivní (výhledové) hledisko. Zaměříme se na přístupy, jež mohou jedince emancipovat, osvobodit jej od „předem daných" alternativ. $V$ tomto kriticky založeném př́stupu se často zdůrazňuje role přiběhů, které formují osobnost člověka, což se děje většinou neuvědoměle - Ben Okri (viz např. 1992) mluví o tom, že př́běhy jsou tajemné a mocné. Dělají svou práci v tichosti, jsou neviditelné. Pracují se všemi „materiály" mysli a osobnosti. Stávají se naší součástí, a zároveň nás mění. Dejte si pozor na př́běhy, které čtete nebo vyprávíte; nenápadně, v noci, pod hladinou vědomí, mění váš svět. K tomu dodává Salman Rushdie (1991), že př́běhy tak mají skutečnou moc - tím, že formují podobu minulosti, utváŕí také budoucnost: "Ti, kdo nemají moc nad př́během, který ovládá jejich život, moc ho převyprávět, proměňovat, rozebrat jej, parodovat a měnit $v$ závislosti na tom, jak plyne čas, jsou ti skutečně bezmocní, protože nemohou vytvářet nové myšlenky."

Narativy jsou kognitivní struktury, které nám pomáhají uspořádávat, chápat a popisovat svět, jsou to "verze reality, jejichž přijatelnost je dána konvencí a "narativní nutnostî spíše než empirickým ověřením a logikou" (Bruner, 1996), což znamená, že často věříme př́běhům ne proto, že by byly pravdivé, ale protože souzní s našimi hodnotami (Canning a Reinsborough 2010, str. 21). Podstatou působení těchto príběhů je to, že se v nich informace získávané prostřednictvím různých médií (text, film, vizuální umění atd.) dokáží seskupit do snadno pochopitelných, kulturně specifických forem, které procházejí všemi oblastmi našeho života: "Sníme v narativech, lelkujeme v narativech, skrze narativy vzpomínáme, očekáváme, doufáme, zoufáme si, věř́me, pochybujeme, plánujeme, revidujeme, kritizujeme, konstruujeme, klevetíme, učíme se, nenávidíme a milujeme. " říká Barbara Hardy (1968). Tématem využití narativů se zabývá Hnutí za změnu, jehož členové pochopili, že „....lidé nepotřebují nová fakta - potřebují nový př́běh... změňte jejich př́běh a změníte i jejich chování" (Hopkins, 2019). Při utváření narativů hraje klíčovou roli umění. Uměleckou výpovědí vyjadřujeme své sny a můžeme je pak sdílet s ostatními. Síla umění také pomáhá vytvářet představu nového já, nového života, což je prvním krokem k jeho uskutečnění; tyto sny a obrazy 
často čerpají ze spontánního vědění, které nesouvisí s myšlením (Silverstone 1997). Prozatím se ale tento prístup uplatňuje hlavně jako základní strategie využívaná v terapiích uměním.

Měli bychom vědět, že změna může přijít, pouze pokud se nebudeme soustředit na to, co nechceme, ale zaměříme se na to, co si přejeme. To vyžaduje, abychom rozpoznali hlavní způsoby "kontroly" př́běhů, které "normalizují status quo, zakrývají alternativní možnosti nebo vize... fungují jako hranice politické představivosti a utvářejí dominantní kulturu" (Canning a Reinsborough 2010). Když si uvědomíme, jak př́běhy či mytologie ovládají náš svět, můžeme začít znovu - $s$ představou světa, který chceme. Můžeme se poučit $z$ dřívějších úspěšných hnutí za změnu - at́ již jde o občanská práva, práva menšin a feministická hnutí, abychom jmenovali jen několik, která využila představivost a vytváření nových príběhů jako nástroj k zahájení skutečných a trvalých změn $\mathrm{k}$ lepšímu. Inspirací může být i současná expanze alternativních subkultur - $v$ oblasti spotřeby jsou to např́klad hnutí Do-It-Yourself, komunity založené na kolektivních vzorcích životního stylu a sít Transition Network - které také popírají nutnost přijetí statu quo, vedou k odmítnutí konzumu, masové výroby a ekologické destrukce, a umožňují, aby se v komunitně založených vztazích prosadil nový styl života (Day, 2016).

Synergie umění a vědy pak je cílem hnutí „od STEM k STEAM" ve vzdělávání. Tzv. STEAM Education je zkratka označující takové vzdělávání, které využívá vědu (Science), technologii (Technology), inženýrství (Engineering), umění (Arts) a matematiku (Mathematics) jako hlavní oblasti, které podporují zájem studentů, a pomáhají rozvíjet dialog a kritické myšlení. Samotný STEM (nezahrnuje umění) postrádá několik klíčových komponent, které mnozí zaměstnavatelé, pedagogové a rodiče považují za zásadní pro to, aby se našim dětem dařilo $v$ současnosti i v budoucnosti, která se rychle přibližuje. STEAM posouvá STEM na vyšší úroveň: umožňuje studentům propojit své učení s uměleckými praktikami a prvky, napríklad s principy designu a dalšími nástroji využitelnými při učení. STEAM odstraňuje různá omezení a nahrazuje je údivem, kritikou, dotazováním a inovacemi.

Kreativní učení je pedagogický přístup, který je považován za př́ležitost k propojení různých druhů vědění (Ewing, 2010) a kurikulárních oblastí (předmětů) kolem jedné "velké myšlenky" jako jsou výzvy udržitelnosti a jak si představujeme budoucnost. Více o tomto konceptu v souvisejícím článku Henderson et al. (2021).

\section{Vzdělávání ke kritickému přístupu, Critical futures education (CFE)}

Tento př́stup si klade za cíl zprostředkovat žákům pochopení toho, že své představy o budoucnosti máme zprostředkované převládajícími světonázory, ideologií a kulturou. Je v něm důležitá otázka, proč a jak společnost některým obrazům budoucnosti dává přednost, zatímco jiné jsou na okraji jejího zájmu. Takto má za cíl ukázat více možností budoucího vývoje i to, že tyto alternativy jsou zakořeněny v př́tomnosti, v nás samotných (Ramos 2005: 25).

Psychologický výzkum ukazuje, že lidé mají tendenci ignorovat informace, které nezapadají do jejich současných rámců chápání světa. „Konfirmační zkreslení" (confirmation bias) je hluboce zakořeněné, zapuštěné do systému fungování našeho nervového systému a filtruje informace, které jdou proti našim zažitým předpokladům (Plous 1993). Argumentovat se dá neustále dokola, nebot' slovní přestřelky zř́́dkakdy někoho přesvědčí, aby se na věc podíval z nové perspektivy, pokud nechce. Narušování normativních diskurzů, vybízení k hledání alternativ a poskytování prímých zkušeností s alternativní, chtěnou verzí budoucnosti jsou taktiky, které používají umělečtí aktivisté na celém světě. Umění zostřuje naše kritické povědomí, podporuje „....nové způsoby vnímání a interpretování světa, má potenciál kreativně potlačovat psychickou manipulaci, strategickou dětinskost a sedativní diskurzy" (Andel, 2015). 
Analýza budoucnosti optikou různých ideologií (tržní kapitalismus, marxismus, ekofeminismus, technologický optimismus, náboženský fundamentalismus) může tuto pluralitu budoucností ilustrovat (Wagar, 2002), přičemž obecně přijatá podoba této budoucnosti závisí na převládajícím světonázoru. Média často vykreslují budoucnost v extrémech: jako budoucnost dystopickou či apokalyptickou, nebo techno-utopickou, což formuje pocity veřejnosti, zavádí je bud' do falešného zoufalství, nebo falešných očekávání (Ramos 2005: 26). Oba scénáře pěstují dojem, že nad lidmi vládnou mocné síly, a tak je možné se účastnit veřejného života pouze pasivně, ve vyhrazeném prostoru a čase. "Dekolonizace" budoucnosti vyžaduje, abychom si uvědomili, čím jsou utvářeny naše představy o ní; následovat by měly aktivity občanů a komunit, zaměřené na znovuzískání vlivu na podobu této budoucnosti, kterou dosud ovlivňoval stát nebo jiní vlivní hráči ve společnosti (Ramos, 2005).

\section{Myšlení budoucnosti jako součást transformativního vzdělávání}

"Transformace" se stala termínem, který je často užíván v literatuře a v opatřeních týkajících se udržitelnosti a ve vzdělávání pro udržitelnost (VU). Dosažení této transformace je popisováno jako třetí a nejdůležitější součást vzdělávání pro udržitelnost, přičemž hledisko budoucnosti je základem druhé složky (UNECE, 2011):

\section{Holistický přístup}

Holistický př́stup zahrnuje tři provázané komponenty:

a) Integrativní myšlení; b) Inkluzivita; c) Zvládání složitých situací.

\section{Předjímání změn: minulost, prítomnost a budoucnost}

Předjímání změn zahrnuje kompetence týkající se tří oblastí:

a) Poučení se z minulosti; b) Podněty k angažovanosti v př́tomnosti; c) Objevování alternativních budoucností.

\section{Dosažení transformace: lidé, pedagogika a vzdělávací systémy}

Dosažení transformace zahrnuje kompetence, které fungují na třech úrovních:

a) Transformace role pedagoga; b) Transformace pedagogiky, tj. transformativní prístupy k učení a učení se; c) Transformace vzdělávacího systému jako celku.

Termín transformativní učení označuje jak pedagogický př́stup, tak i jeho účinek na studenta; Jack Mezirow (2003) ho definuje následovně:

„Transformativní učení je takové učení, které přetváři problematické referenční rámce - soubory fixních předpokladů a očekávání ("návyky" mysli [v originále habits of mind], významové perspektivy, způsoby uvažování) - a činí je inkluzivnějšími, zdravě kritickými, otevřenými, přemýšlivými a schopnými se emocionálně měnit... Referenční rámce bereme za samozřejmé a patři mezi ně zažité mezilidské vztahy, politická orientace, kulturní předsudky, ideologie, schémata [myšlení a zvyklostí], stereotypní př́stupy a praxe, profesní zvyklosti, náboženské doktríny, morální a etické normy, psychologické preference a schémata, paradigmata ve vědě a matematice, rámce $v$ lingvistice a sociálních vědách a estetické hodnoty a standardy." (Mezirow, 2003)

Tato definice byla sice vytvořena v kontextu vzdělávání dospělých, i děti jsou však schopné kriticky zkoumat domněnky, kulturní předsudky a stereotypy; tím potom reagovat 
např́klad na formy útisku marginalizovaných komunit (Bivens et al., 2009; Yelland \& Arvanitis, 2018).

Transformativní učení se nemusí nutně zastavit na úrovni osobní transformace: „Teorie transformativního učení ř́ká, že proces transformace, založený na změně perspektivy, má tři dimenze: psychologickou změnu (změny $v$ porozumění sobě sama), změnu přesvědčení (revize systémů víry) a změnu $v$ chování (změny životního stylu). $K$ těmto závěrům dospěl současný výzkum transformativního učení pro udržitelný rozvoj (Boström et al., 2018), který analyzuje možnosti změn v praxi." (Dlouhá et al., 2021). Termínem "transformativní" $v$ této práci popisujeme takové vzdělávání, na jehož základě si žáci uvědomí, že mohou přispívat k sociální změně, pokud si budou klást otázky, představovat si a aktivně vytvářet takovou budoucnost, jakou si přejí (takto byl termín definován již v předchozím článku).

Výzkum prokázal, že děti se mohou stát se hybateli změn ve formálním i neformálním vzdělávání (Chawla, 2002, Heft and Chawla, 2006, Cocoran and Osano, 2009, Percy-Smith and Thomas 2010, in Percy-Smith and Burns, 2013). Theis (2010) navrhuje, aby děti projevovaly své občanství ve veřejných záležitostech v různých oblastech, např. ve školách, médiích, ve sportu a kultuře, a tvrdí, že mnoho dospívajících tuto zodpovědnost přijímá a bere na sebe veřejné role. Existuje bezpočet inspirativních vzorů: Malala Yousafzai a její kampaň za právo dívek na vzdělání; Greta Thunberg, která iniciovala stávky Fridays for Future protestující proti nečinnosti vlád k tématu klimatických změn; Autumn Peltier z domorodé rezervace Wikwemikong $v$ Severním Ontariu $v$ Kanadě, která od svých osmi let bojuje za čistou vodu a vystupuje na národních i mezinárodních politických akcích; Isra Hirsi ze Spojených států, která upozorňuje na environmentální rasismus a založila americkou verzi stávek za klima; odbory dětských dělníků v Indii; dětský parlament v Bolívii, který podnítil legislativní reformy, jež měly pozitivní vliv hlavně na domorodé komunity; dětmi vedené mírové hnutí v Kolumbii; nebo hájení zájmů dětí dětmi na Filipínách, což pak přispělo ke zlepšení školských zařízení a přístupu k učebnicím (Austin, 2010, Theis, 2010).

\section{Vzdělávání pro udržitelný rozvoj}

Vzdělávání pro udržitelný rozvoj (VUR) je rámec, který reaguje na měnící se potřeby společnosti a rychle se zhoršující environmentální situaci. Volně definuje budoucí, kýžený stav; popisuje potřebné změny návyků v myšlení a chování; a navrhuje pedagogický přístup, kterého je třeba, aby mladí lidé uskutečnili změny a směřovali k vytouženému cíli. UNESCO (2015) popisuje VUR takto:

"VUR vede studenty $k$ tomu, aby na základě informovaných rozhodnutí a zodpovědného jednání směřovali k ekologické integritě, ekonomické proveditelnosti a spravedlivé společnosti pro současné a budoucí generace, a přitom respektovali kulturní rozdílnosti. Jeho cílem je celoživotní učení jakožto integrální součást kvalitního vzdělání. VUR je holistické a transformativní vzdělávání, které se klade důraz na obsah a výstupy učení, ale i pedagogikou a prostředí pro učení. Dosahuje svého cíle proměnou společnosti."

\section{Další pedagogické přístupy využívající umění pro podporu schop- nosti jednat a měnit svět}

$\checkmark$ této části se zaměříme na pedagogické přístupy, které nabízejí různé cesty ke změně - předjímají tedy určitý vliv na budoucnost. Patři mezi ně např́klad kritická pedagogika, pedagogika sociální spravedlnosti neboli aktivistická pedagogika, ekologické vzdělávání, vzdělávání vycházející z místa a vzdělávání k aktivnímu občanství. Zkoumáme zároveň roli umění $v$ těchto různých přístupech, a ilustrujeme tím šírí a hloubku, kterou nabízí kreativní učení (nejen) pro imaginaci budoucnosti a její následné uskutečnění. Tato různorodost ukazuje, že existuje mnoho účinných př́stupů, které se hodí pro různé vzdělávací situace. Umění zde 
zajišt́uje, že dopad vzdělávacích aktivit je celostní - zasahuje nejen kognitivní, ale i sociální a emocionální doménu.

Kritická pedagogika uznává, že vědění není nikdy bezhodnotové nebo politicky neutrální, a učení je tedy inherentně politické, at explicitně nebo implicitně. Kritická pedagogika vychází z klíčové práce Paolo Freirea Pedagogika utlačovaných a podporuje reflexi situace lidí žjících $\checkmark$ podmínkách útlaku (na základě třídy, rasy nebo pohlaví) s cílem osvobodit se od tohoto útlaku (Friere, 1996). Vychází z kritické teorie a jejích součástí, např. z postkoloniální teorie a feminismu, a zkoumá, dekonstruuje a znovu buduje naše společnosti tak, aby lidé měli stejnou možnost rozvíjet svůj potenciál.

Apple (2013) se ptá, jakou má vzdělávání roli v překonávání sociální nespravedlnosti:

„Většina národů - a vznikajících národů - má ve své historii osobnosti, které kladly kritické otázky týkající se školství a politiky vědění, jejihž byly součástí. Reprodukuje vzdělávání jen ideologické cíle a kulturní formy a obsahy dané dominantními skupinami? Je možné ve vzdělávání nastolit témata týkající se současných společností? Mohlo by toto vzdělávání jít ještě dál a začít fungovat tak, aby se aktivně účastnilo transformace těchto společností?" (Apple 2013)

Kritická pedagogika využívající umění sice vychází z teorie Paola Freireho, který se snažil posílit vliv venkovské chudiny v Brazílii, stal se $z$ ní však především městský fenomén. Využívá se ve formálním i neformálním vzdělávání v marginalizovaných komunitách trpících sociální a ekonomickou nespravedlností, protože pomáhá zvýšit povědomí žáků o vlastním útlaku a dát jim sílu bránit se zaběhnutému stavu věcí. Během procesu uvědomování si, otevřené reflexe vlastní situace vzniká trvalé nebo dočasné umělecké dílo (př́íkladem jsou různé druhy veřejného umění jako malování na zdech nebo pouliční představení mezi lidmi atd.), díky němuž jsou autoři viditelnější a jejich hlas je více slyšet.

Rautins a Ibrahim (2011) vycházejí z konceptu zvědomování Paula Freireho (posilování uvědomění studentů, což jim pomůže odhalit útlak, jemuž jsou v dané situaci vystaveni, a poskytne jim určitou moc) a konceptu bdělosti Maxine Greenové (aktivní vnímání toho, jak sami zakouší svět) - navrhují kritickou pedagogiku naděje a kreativity, kde je umění zkouškou ohněm pro "kritickou pedagogiku představivosti" (tamtéž str. 28). Kreativita je spojená s představivostí a její schopností „vytvářet nové reality, možná i nové světy" (Greene, 2007, in Rautins and Ibrahim 2011) a "nabízet studentům bohaté príležitosti k učení se, aby mohli sami vytvářet významy a vymýšlet a otevírat možnosti nových interpretací a pochopení" (tamtéž str. 28). Do přístupů kritické pedagogické založené na umění můžeme zařadit i př́padovou studii Meenah Neenah popsanou výše.

Umělecké vzdělávání pro sociální spravedlnost/Aktivistická pedagogika vychází z kritické pedagogiky a bývá označována různými termíny - komunitní umění, aktivistické umění, kulturní rozvoj komunity, divadlo utlačovaných, umění pro sociální změnu, umění pro demokracii, umění sociální praxe. Všechny tyto formy mají společnou snahu o umělecké vyjádření, které přitahuje pozornost, mobilizuje aktivitu a zasahuje $v$ systémech nerovnosti či nespravedlnosti (Dewhurst 2014). Umění dokáže předávat myšlenky tam, kde selžou slova, zpochybňuje dominantní hodnoty, poskytuje př́ležitost zabývat se koncepty, které jsou těžko vysvětlitelné, zviditelňuje marginalizované či umlčené hlasy. Kritické vzdělávání nebo vzdělávání pro sociální spravedlnost je užitečným rámcem pro zapojení aktivistického umění do výuky. Zde je důležité si uvědomit tři hlavní atributy výchovy k sociální spravedlnosti - je to proces vycházející z lidské zkušenosti, sestává z reflexe a jednání, a snaží se rozložit systémy nerovnosti, aby vznikla humánní společnost (Dewhurst 2014); tento přístup klade důraz na aktivitu mladých lidí. Stejně jako kritické pedagogické přístupy je výchova k sociální sprave- 
dlnosti programem rekonstrukce: využívá uměleckou výchovu jako způsob zkoumání, zapojování a transformování komunity (Inwood, 2008 str. 32). Př́padová studie Projekt Billy ilustruje aspekt transformace komunity, který je popsaný $v$ tomto prístupu.

Finley (2011) popisuje eko-estetickou pedagogiku jako aktivistické umění „shodující se s ostatním aktivistickým uměním v základních znacích, včetně těch, že (a) vychází z tělesného prožívání místa/prostoru, (b) bere vzdělávání a účast veřejnosti jako nástroj sociální transformace, (c) uplatňuje etiku péče skrze kulturní pluralismus a spolupráci a (d) je performativní, zaměřené na jednání, a je i politicky transformativní. Skrze jazyk a obraz, které reflektují místní mluvu a prostředí, je na osobní i kolektivní rovině ztělesňována kritická, ekoestetická pedagogika."

Ekologické umělecké vzdělávání je zakotveno v ekologickém vzdělávání a přírodopisu a vyrostlo z hnutí ekologického umění, jež se inspirovalo environmentalismem 60 . let 20. století. Ekologické umělecké vzdělávání zdůrazňuje učení se o komplexnosti životního prostředí ne skrz racionální, kognitivní přistup tradiční výuky vědeckých oborů, ale s využitím smyslového, afektivního přistupu (Inwood 2008). Jeho cílem je usnadnění vnímání, tím, že prírodní jevy jsou sledovány zblízka a pomocí přimé zkušenosti. Tato zkušenost dává podle různých výzkumných studií ekologickému uměleckému vzdělávání schopnost vyvolávat pocity empatie vůči prírodě (Bradshaw, 2016; Weir, 2016, in Conkey and Green, 2017; Bertling 2015). Ekologické vzdělávání bývá kritizováno pro nedostatečnou pozornost k sociální nespravedlnosti a za to, že zapomíná na znevýhodněné obyvatele městských prostředí, kteří si luxus kontaktu s př́rodou nemohou dovolit.

Není to tak ale vždy. Suzi Gablik je zásadním hlasem v rozvoji teorie eko-uměleckého vzdělávání (1991, 1995). Její teorie spojené estetiky zpochybnila nevztahový, "odpojený, izolovaný přistup ,bezhodnotového' vědomí" běžného $v$ modernistickém umění a postavila se za estetiku pro sociální změnu. Hnutí ekologického umění se snaží zapojit veřejnost, propagovat a utvářet ekologické hodnoty (Wallen 2012, ve Conkey and Green 2018) tak, jak se to vědcům nepovedlo (Inwood, 2008). Blandy a Hoffman (1993) vyšly z Gablikové a čerpali z ekologické teorie a uměleckého vzdělávání vycházejícího z komunity. Formulují tak umění coby „způsob zapojení jednotlivců do sociálních a politických témat tak, že získají moc, spojí se a založí komunitu" a jejich přístup učí vzájemnosti a propojenosti (Blandy and Hoffman 1993 in Inwood 2008 p62).

Anderson a Guyas (2012) přehledně popisují, jak je umělecké vzdělávání a ekologické vzdělávání propojeno, a ukazují, jak mohou oba tyto vzdělávací přístupy (synergicky) podpořit etické ekologické chování a nabídnout principy pro výuku Earth Education (výuku o zemi skrze umění). Zde jsou využity principy spolubytí a hlubinné ekologie, kam patří probouzení smyslů, pozitivní emocionální investice, zkušenost tělesnosti, práce s metaforou, propojení kritického uvědomění, emoce a jednání, rekontextualizace sebe sama skrze spolubytí, epistemologie vycházející z místa, oživení uměleckých znalostí coby modelu pro pochopení př́rody a mezioborová a sociálně/politicky angažovaná pedagogika.

Místně zakotvené učení, kritické vzdělávání vycházející z místa a integrující umění: Koncept "nemísta", který popisuje odcizení lidí ve větších systémech (Auge, M. 1995 in Thomson, P. et al., 2012), je ve vzdělávání čím dál relevantnější. Mezi nemísta patří napríklad letiště, kde jsou lidé ztotožněni s číslem palubního lístku, nemocnice, kde jsou redukováni na diagnózu, poznámky lékaře a čekací lhůty, a obchody, kde jsou pouhými konzumenty, jejichž preference jsou analyzovány a předvídány. Školy fungují instrumentálně, určující jsou tu testy, známky a hodnocení; tyto vzdělávací instituce tak mají daleko ke vzdělávání, jehož středobodem je člověk (Fielding 2006, in Thomson, P. et al., 2012). Na druhé straně existují způsoby, jimiž je možné podpořit pocit ukotvenosti a př́slušnosti k místní komunitě spolu $s$ vědomím globálního kontextu. 
Feministická geografka Linda McDowell upozorňuje, že místa jsou „sporná, proměnlivá a nejistá: prostředí jsou kulturní, sociální a politické konstrukty (1999). Prostředí přitom znamená víc než ekologické systémy a biologické sítě, do nichž jsme zasazeni: třída, rasa, historie, vlastnictví půdy a její uživání fungují jako rámce pro ekologické a biologické vztahy v daném místě (Cole 2007). Vzdělávání vycházející z místa reflektuje důležitost místa při formování identity (hooks 2009, in McInerney et al 2011), uznává však i lidský a kulturní aspekt místa.

Místně zakotvené učení (place-based education - PBE) poskytuje vzdělávací kontext, který chápe studenty jako tvưrce, nikoliv konzumenty vědění (Smith 2007, in McInerney 2011). Sobel (2005) tvrdí, že PBE „pomáhá studentům rozvíjet silnější vazby na svou komunitu, najít vztah k prrírodě a stát se aktivním, prospěšným občanem". PBE nevychází z konkrétního teoretického základu, ale „je možné chápat jeho praxi a cíle jako vycházející ze zkušenostního učení, kontextuálního učení, učení souvisejícího s řešením problémů, konstruktivismu, vzdělávání venku, domorodého vzdělávání, environmentálního a ekologického vzdělávání, bioregionálního vzdělávání, demokratizujícího vzdělávání, multikulturního vzdělávání, vzdělávání založeného na komunitě, kritické pedagogiky." PBE se často zaměřuje na konkrétní venkovské a ekologické zdroje učení, přičemž v tomto kontextu opomíjí podíl sociokulturních rozdílů, nerovností a politiky na zhoršující se ekologické situaci (Gruenewald 2003 in Graham 2007).

- V reakci na globalismus se PBE soustředí na důležitost lokálních aktivit; je ukotveno v místě a bývá tak kritizováno za to, že se př́liš věnuje lokálním problémům na úkor pochopení souvislostí mezi globálními a lokálními jevy (Gruenewald 2003, Furman and Gruenewald 2004), a že podporuje tendenci vidět sociální a ekologické problémy jako řešitelné na lokální úrovni, aniž by bralo $v$ potaz národní, regionální a globální síly (McInerney et al 2011). Zároveň ale může jako lupa "jasně ukazovat propojení mezi globálním kapitalismem a ničivým dopadem ekonomického vykořistování a kulturního útlaku na lokální komunity" (tamtéž). Gruenewald propaguje kritický pedagogický přistup k PBE: rozvíjí tak kritické místně zakotvené učení. Spojení uměleckého vzdělávání s tímto př́stupem, navíc obohaceným o prvky ostatních pedagogických přístupů popsaných výše, "[stírá] hranice mezi uměleckou tvorbou, sociální kritikou, vědeckým bádáním a aktivismem. ... Umělecká tvorba je chápána jako způsob relevantního vyjádření, které má vliv na sociální vědomí a volá po změně. ... Umění nás nutí odpoutat se od návyků konvenčního uvažování a přemýšlet o tom, pro co žijeme." (Graham 2007).

\section{Imaginace budoucnosti a její role (nejen ve vzdělávací praxi)}

Důležitou roli při představování si budoucnosti hraje umění. Naše představivost a schopnost snít o změně nás samotných byla hybnou silou vývoje lidstva po dlouhé tisíce let. Když i nyní budeme naši schopnost kolektivní představivosti brát vážně, povede se nám překonat zažitý dojem, že k současnému systému "neexistuje alternativa", což jsou slova Margaret Thatcherové. Jaké jsou nástroje či prostředky této schopnosti imaginace? Takto mohou sloužit např́ílad príběhy o lepší budoucnosti, které už v minulosti dokázaly změnit lidskou kulturu: biblický popis země zaslíbené, ráj; Platónova vysněná Republika; Utopie Thomase Morea; proslov Martina Luthera Kinga, který začíná známými slovy "Mám sen" (Duncombe 2012). Představivost se projevuje sněním, vyprávěním př́běhů, hraním si, nebo při tvorbě a při různých uměleckých činnostech. Umění je „projevem představivosti a kreativity, schopností, které mají zásadní dopad na jednotlivce a komunitu" (Anděl, 2015).

"Imaginace budoucnosti" a vědomá práce s myšlenkami na ni se i nyní prosazuje $v$ mnoha oblastech, a provádí se různými metodami a př́stupy. Mají společné to, že jejich 
cílem je "dekolonizovat" budoucnost, posílit představivost a pohlížet na budoucnost z různých úhlů pohledu, pluralitně.

Jak se s budoucností pracuje v politice:

- Cíle udržitelného rozvoje představují globální, participativní cvičení při hledání lepší budoucnosti; jsou celosvětovým plánem, ke kterému jsou také vytvořeny indikátory, aby bylo možné sledovat postup $k$ dosažení vytčených cílů.

- Rada pro světovou budoucnost (WFC) usiluje o předání zdravé a udržitelné planety se spravedlivým a mírumilovným společenským uspořádáním našim dětem a vnoučatům. Aby toho dosáhla, zaměřuje se na vytváření a šíření účinných politik, které by dokázaly čelit současným výzvám, a podporuje jejich zavádění po celém světě.

Jak řeší budoucnost občanská společnost

- Příkladem toho, jak je myšlení budoucnosti využito v praxi, je Transition Network: hnutí komunit, které záměrné používají imaginaci pro hledání nových možností, jak obnovit náš svět.

- Centrum pro strategie vycházející z príběhů (The Centre for Story-based Strategy) vyvinulo metodiky a nástroje, $v$ nichž hlavní roli hraje představivost a práce $s$ príběhy - tyto metody pak používají pro kampaně a nastartování změn. Publikovali např́iklad Re: Imagining Change (Canning a Reinsborough 2018)

- Centrum aktivismu v umění (Centre for Artistic Activism) zase hledá možnosti, jak vstupovat do angažovaného společenského dialogu prostřednictvím umění.

Myšlení budoucnosti se uplatňuje i ve vzdělávání; zde můžeme využít například:

- Koncept vzdělávání o budoucnosti, nebo transformativního vzdělávání pro udržitelný rozvoj (Dlouhá et al., 2021; Henderson et al., 2021);

- Zdroje pro výuku Světové federace pro studium budoucnosti https://library.teachthefuture.org/

- Zdroje vzdělávacího projektu Futuropolis, založené na kritické pedagogice, systémovém myšlení a modelování budoucnosti, které poskytuje bohatou a neustále se rozvíjející nabídku online zdrojů pro školy o tématech, jako je kultura znásilnění, otázky LGBTQ+ a změna klimatu. https://www.futuropolis.cz/

- metodika vyvinutá v projektech Vzdělávání pro budoucnost a Školy pro budoucnost, která vznikla ve spolupráci Společnosti pro kreativitu ve vzdělávání a Centra pro otázky životního prostředí Univerzity Karlovy (Henderson a Kuříková, 2021).

\section{Jak se vypořádat se svými předsudky o budoucnosti a jak je zkou- mat?}

Přestože vytváření vize budoucnosti a práce na jejím naplnění musí být kolektivním dílem, je užitečné nejprve provést určitou introspektivní práci - tak si lépe uvědomíme své implicitní předsudky nebo přesvědčení, které ovlivňují naše vnímání budoucnosti. Zde je potřeba klást si otázky, jak byly naše představy formovány - např́klad:

- Co ovlivnilo naši představu o budoucnosti? 
- Jaké príběhy souvisejí s našimi předpoklady? Experimentujme s nezvyklými pohledy a zkusme si predstavit budoucnost jinak.

- Jak vnímáme média, když hovoří o budoucnosti? Jak obrazy popkultury utvářejí představy o budoucích možnostech?

- Položme si otázky "Co kdyby...?" a "Proč ne?" - uvidíme tak, jak moc by se naše mysl mohla otevř́t alternativním možnostem budoucnosti.

- Na koho vzpomínám, nebo si uvědomuji, že formoval budoucnost?

- Jakou roli mám já sám při utváření své vlastní budoucnosti a budoucnosti své komunity?

Budoucnost spočivá právě ted' v nás samotných. Každé naše rozhodnutí utvárí naši budoucnost i budoucnost ostatních. Můžeme se zamyslet nad tím, jak v minulosti formovalo budoucnost společné úsilí v oblastech, jako je věda nebo lidská práva. Mohou nás také inspirovat příběhy obyčejných lidí a skupin, kteří se rozhodli pracovat na změně a byli úspěšní.

\section{Jak hodnotit sebe ve vztahu k budoucnosti?}

Vybudovat si vlastní představu o budoucnosti není úplně snadné. Kromě osobních hledisek a zájmů je přitom také potřeba se zamyslet nad obecnými hodnotami, které do našich představ o budoucnosti vstupují. Pokud jsem odhodlán budovat spravedlivou a udržitelnou budoucnost, mohu si klást otázky jako:

- Jsou moje činy v souladu s lidským (i více-než lidským) světem?

- Beru víc, než dávám? Je moje chování „Vykořistovatelské"?

- Co mohu udělat pro nápravu a obohacení světa?

- Jsem ve svých rozhodnutích solidární s jinými lidmi a komunitami, blízkými i vzdálenými?

- Prospívají mé činy jen mně nebo též ostatním? Zahrnuji do svých aktivit všechny, nevylučuji nikoho?

- Dokážu spíše spolupracovat než soutěžit?

Jak provádět sebehodnocení - zeptejte se sami sebe:

- Umím své předpoklady o budoucnosti kriticky posoudit (dekonstruovat)?

- Jsou kulturní akce či média, na které se dívám, inspirativní a podnětné, pomáhají mi zpochybňovat mé předsudky?

- A hlavně: Mám naději do budoucnosti?

Pokud ne, pak je vaše představivost stále kolonizovaná! Zde je pak třeba hledat zdroje, lidi a organizace, které provádějí změny. Anebo si přečíst literaturu sci-fi, která zpochybňuje dystopické obrazy budoucnosti.

Pokud ano, jste na správné cestě! 


\section{Spoluvytváření kolektivních vizí budoucnosti}

Budoucnost se týká nás všech, a proto by úvahy o tom, jakou budoucnost si zvolíme, měly mít demokratický a participativní charakter. Pro participativní vytváření vizí budoucnosti existují různé participativní metody. Níže je uvedena aktivita pro vytváření vizí, kterou vyvinula sít Transition Network.

\section{Zkoumání světa po tranzici}

Co se má změnit, co vám vadí na současném stavu, co brání dobrému životu? Rozdělte se do skupin po nejméně 3 lidech, které si mezi sebou rozdělí jedno nebo více z následujících témat - a př́ípadně další témata, která by účastníci chtěli přidat:

- $\quad$ Energie a zdroje

- Z Životní prostředí včetně změny klimatu a dalších otázek znečištění

- $\quad$ Rovnost a začlenění, sociální a osobní blaho

- $\quad$ Ekonomika - včetně růstu, finančních institucí a struktur.

Věnujte ve skupině 10 minut brainstormingu o věcech, které nefungují a které jsou pro vás důležité, způsobují problémy, nebo je třeba je změnit. Pokud máte k dispozici velký papír, zapište si své odpovědi, aby ostatní mohli vaše myšlenky vidět. Nepouštějte se do hádek pokud se neshodnete, prostě uvedte všechny názory vedle sebe.

Každá skupina pak bude mít 2 minuty na to, aby podala zprávu celé skupině.

\section{Jak bude vypadat život po změně (post- transition future imagining)?}

Věnujte 5 minut tomu, abyste si představili, že se projdete po své komunitě v budoucnosti a uvidíte, kde se věci vyvíjejí stejně dobře nebo lépe, než jste si dokázali představit, a problémy, které jste identifikovali, byly vyřešeny pozitivním zpưsobem (nemusí to být "realistické", pokud nechcete). Můžete si vybrat jednu oblast života (výroba potravin, výchova dětí, bydlení, živobytí nebo cokoli jiného), kterou budete zkoumat, nebo si jen představte, že se projdete a všimnete si, co v té budoucnosti je a jak se to dále vyvíjí.

Ve dvojicích nebo trojicích se podělte o některé nápady - co si představujete, že by ve vaší komunitě mohlo být. (5 až 10 minut).

\section{Sdílení vizí, diskuse v plénu}

Vrat́te se do celé skupiny a 5-10 minut v tichosti pište a kreslete na společný papír slova nebo obrázky, které ukazují, co by podle vás mohla budoucnost obsahovat. At je to zábavné a zcela libovolně podrobné nebo vizionářské!

Věnujte 10 minut společnému pohledu na to, co jste vytvořili, a dejte každému př́ležitost vyjádřit se k následujícím otázkám: Co je na papíře - co vaše společná vize zahrnuje? Jaké to bylo představovat si tuto budoucnost - co vás překvapilo, co se vám líbilo nebo nelíbilo? mluvili?

Společně se zamyslete nad tím, co je ve vaší společné vizi. Řeší výzvy, o kterých jste

Existují příklady projektů na národní úrovni, které vyzývají ke společnému vytváření představ o budoucnosti (za široké účasti občanů). Finsko využilo spolupráce s organizátory 
Světového dne budoucnosti v rámci Projektu tisíciletí a vyhlásilo 1. březen finským dnem budoucnosti. Akce se konají po celém Finsku, ve školách, obcích i firmách, kde se lidé zapojují do virtuální Rady budoucnosti a zkoumají alternativní a žádoucí vize budoucnosti. $\mathrm{K}$ dispozici jsou hry a zdroje (také $v$ angličtině), které podporují vytváření představ o žádoucí budoucnosti: https://tulevaisuuspaiva.fi/in-english/

\section{Příklady úspěšných hnutí za lepší budoucnost}

I ve vzdělávání Ize využít př́íklady dobré praxe, a to jako podněty pro přemýšlení i aktivity $v$ praxi:

- Transition Network: príběhy místních komunit spolupracujících na budování sociálně odolných nízkouhlíkových společenství https://transitionnetwork.org/stories/21-stories/

- Otevřená kniha sociálních inovací: Metody a nástroje pro inovace používané na celém světě a v různých oborech - ve veřejném a soukromém sektoru, občanské společnosti a v domácnostech, a to $v$ překrývajících se oblastech jako je sociální ekonomika, sociální podnikání a péče o životní prostředí: https://youngfoundation.org/wp-content/uploads/2012/10/The-Open-Book-of-Social-Innovationg.pdf

- Příkladem z českého prostředí je projekt JSNS (dříve Jeden svět na školách): „Kdo jiný? Podporujeme mladé lidi, aby se aktivně podíleli na př́běhu svého okolí". Inspirativní př́klady projektů jsou k dispozici online: https://www.jsns.cz/projekty/kdojiny/kdo-jiny-/minule-rocniky

$\checkmark$ těchto př́kladech Ize najít inspiraci a taky energii potřebnou $k$ převzetí odpovědnosti za věci, které může změnit jednotlivec, i za ty, na které je třeba jít společnými silami. Aktivní občanství může mít mnoho podob, od tradiční "stranické" politiky, přes aktivity občanské společnosti, jako je Transition Network, až po občanský aktivismus.

\section{Závěr}

Vzdělávání pro budoucnost se nejlépe uplatní tam, kde jsou současně využívány metody transformativního učení. Schopnost představit si (žádoucí) budoucnost je jedním z hlavních předpokladů toho, že ji dosáhneme - že ve společnosti nastane dlouho očekávaný obrat k lepšímu, a tím se zlepší i náš osobní život. Tento text je tak potřeba číst jako součást príbuzného textu věnovaného vzdělávání pro odpovědnou spotřebu (a transformativnímu učení v jejím rámci); ten je ovšem pro přehlednost publikován zvlášt́ (Dlouhá et al., 2021).

Myšlení budoucnosti je ovšem možno rozvíjet také samostatně. Jde o perspektivu, která v českém vzdělávacím systému bolestně chybí. Právě $s$ tímto nedostatkem souvisí i značná část jeho kritiky, třebaže $v$ ní je otázka budoucnosti často implicitní, neuvědomělá. Kde se však vzdělávání týká pouze minulosti, děti a studenti se učí pouze reprodukovat myšlenkové vzorce a minulé praktiky; nedokáží pak být aktivní a formovat společenský vývoj, neumí zvládat rizika budoucích možných scénářů. Pokud se navíc prosazují romantické představy o tom, "jak to bylo kdysi", může být výsledkem jistý fundamentalismus, který se projevuje nedůvěrou ke všemu novému, a dokonce může být zneužíván politiky, jejichž osobní přiběhy jsou s minulostí spjaty. Kvalitní vzdělávání pro budoucnost může nejen otevř́t nový pohled na sociální možnosti, ale i prostor pro nové přiležitosti napřílad ekonomické; pomohlo by též čelit současným výzvám, bez čehož se neobejdeme. Mezi nejdůležitější z nich je třeba zařadit ty, které jsou spojeny s udržitelným rozvojem: klimatická změna, spravedlnost, lidská práva a podobně. Těmto změnám musí čelit společnost jako celek, ale svým způsobem se 
s nimi musí vyrovnat každý z nás - ideálně tak, že přispěje svým dílem k této "nápravě světa".

\section{Poděkování}

Článek je jedním z výsledků projektu „Vzdělání pro budoucnost” (TL02000081), který byl realizován s podporou Technologické agentury České republiky v rámci programu na podporu aplikovaného společenskovědního a humanitního výzkumu, experimentálního vývoje a inovací ÉTA. Centrum pro otázky životního prostředí UK iniciovalo a uskutečnilo výzkum tak, aby jeho výsledky umožnily reflektovat programy kreativního učení a vzdělávání pro budoucnost naržené Společností pro kreativitu ve vzdělávání. Do nich byli aktivně zapojeni četní učitelé a žáci - za aktivní a podnětný přístup všech děkujeme!

\section{Literatura}

- Ahlqvist, T., \& Rhisiart, M. (2015). Emerging pathways for critical futures research: Changing contexts and impacts of social theory. Futures, 71, 91-104. https://doi.org/10.1016/j.futures.2015.07.012

- Andel, J. (2015). Why democracy needs the arts and culture [2nd Council of Europe Platform Exchange on Culture and Digitisation].

- Anderson, T., \& Guyas, A. S. (2012). E<art $>$ h Education, Interbeing, and Deep Ecology. Studies in Art Education, 53(3), 223-245. https://doi.org/10.1080/00393541.2012.11518865

- Apple, M. W. (2013). Can education change society? Du Bois, Woodson and the politics of social transformation. Review of Education, 1(1), 32-56. https://doi.org/10.1002/rev3.3000

- Austin, S. (2010). Children's participation in citizenship and governance. In A Handbook of Children and Young People's Participation. Routledge. http://nmd.bg/wpcontent/uploads/2013/02/Routledge-A Handbook for Children and Young Peoples Participation.pdf

- Bertling, J. G. (2015). The Art of Empathy: A Mixed Methods Case Study of a Critical Place-Based Art Education Program. International Journal of Education \& the Arts, 16(Number 13). http://www.ijea.org/v16n13/index.html

- Bivens, F., Moriarty, K., \& Taylor, P. (2009). Transformative education and its potential for changing the lives of children in disempowering contexts. IDS Bulletin, 4O(1), 97-108. https://doi.org/10.1111/j.1759-5436.2009.00014.x

- Blandy, D., \& Hoffman, E. (1993). Toward an art education of place. Studies in art education, 35(1), 22-33.

- Boström, M., Andersson, E., Berg, M., Gustafsson, K., Gustavsson, E., Hysing, E., Lidskog, R., Löfmarck, E., Ojala, M., \& Olsson, J. (2018). Conditions for transformative learning for sustainable development: A theoretical review and approach. Sustainability, 10(12), 4479. https://doi.org/10.3390/su10124479 
- Burnaford, G., Brown, S., Doherty, J., \& McLaughlin, H. J. (2007). Arts Integration Frameworks, Research Practice- A literature Review. http://choice.dadeschools.net/rrm/resources/BurnafordArtsIntegrationFrameworksResearchPracticeALitReview.pdf

- Bradshaw, R. D. (2016). Art Integration Fosters Empathy in the Middle School Classroom. The Clearing House: A Journal of Educational Strategies, Issues and Ideas, 89(4-5), 109-117. https://doi.org/10.1080/00098655.2016.1170441

- Bruner, J. S. (1996). The Culture of Education. Harvard University Press.

- Canning, D., Reinsborough, P., \& Smucker, J. M. (2017). Re: Imagining change: How to use story-based strategy to win campaigns, build movements, and change the world. Pm Press. ISBN: 978-1-60486-197-6

- Chawla, L. (2002). „Insight, creativity and thoughts on the environment”: integrating children and youth into human settlement development. Environment and Urbanization, 14(2), 11-22. https://doi.org/10.1177/095624780201400202

- Conkey, A., \& Green, M. (2018). Using place-based art education to engage students in learning about food webs. Journal of Instructional Pedagogies, 21. https://eric.ed.gov/?id=EJ1194246

- Cole, A. G. (2007). Expanding the Field: Revisiting Environmental Education Principles Through Multidisciplinary Frameworks. The Journal of Environmental Education, 38(2), 35-45. https://doi.org/10.3200/JOEE.38.1.35-46

- Convention on the Rights of the Child. (1990). UN General Assembly. http://wunrn.org/reference/pdf/Convention Rights Child.PDF

- Corcoran, P. B., Osano, P. M., Weakland, J. P., \& Hollingshead, B. P. (2009). Young People, Education, and Sustainable Development: Exploring Principles, Perspectives, and Praxis. Wageningen Academic Pub.

- Dator, J. A. (2002). Advancing Futures: Futures Studies in Higher Education. Greenwood Publishing Group. ISBN: 0-275-96945-2

- Day, A. (2016). DIY Utopia: Cultural Imagination and the Remaking of the Possible. Lexington Books. ISBN: 978-1-4985-2389-9

- Dewhurst, M. (2014). Social justice art: A framework for activist art pedagogy. Harvard Education Press. ISBN: 978-1-61250-738-5

- Dlouhá, J., Henderson, L., Kroufek, R., Jančaříková, K., \& Neprašová, S. (2020). Udržitelná spotřeba a životní styl jako vzdělávací téma: Jaké vzdělávací cíle si stanovit, když chceme předjímat společenské změny? Envigogika, 15(1). https://doi.org/10.14712/18023061.608

- Dlouhá, J., Henderson, L., Kroufek, R., Jančaříková, K., \& Neprašová, S. (2021). Vzdělání k udržitelné spotřebě a životnímu stylu - cíle a výstupy. Envigogika, 16(1). DOI: https://doi.org/10.14712/18023061.619

- Duncombe, S. (2012). Introduction: Open Utopia | The Open Utopia. http://theopenutopia.org/full-text/introduction-open-utopia/ 
- Ewing, R. (2011). The Arts and Australian Education: Realising Potential. Australian Education Review No. 58. Australian Council for Educational Research. https://research.acer.edu.au/cgi/viewcontent.cgi?referer=https://scholar.google.com/\&httpsredir $=1 \&$ article $=1020 \&$ context $=$ aer

- Finley, S. (2011). Ecoaesthetics: Green arts at the intersection of education and social transformation. Cultural Studies? Critical Methodologies, 11(3), 306-313. https://doi.org/10.1177/1532708611409549

- Furman, G. C., \& Gruenewald, D. A. (2004). Expanding the landscape of social justice: A critical ecological analysis. Educational administration quarterly, 40(1), 4776. https://doi.org/10.1177/0013161X03259142

- Gablik, S. (1992). Connective Aesthetics. American Art, 6(2), 2-7. https://doi.org/10.1086/424147

- Greene, J. C. (2007). Mixed methods in social inquiry (Vol. 9). John Wiley \& Sons.

- Gidley, J., Bateman, D., \& Smith, C. (2004). Futures in Education: Principles, practices and potential, (Monograph No 5; The Strategic Foresight Monograph Series). https://researchrepository.rmit.edu.au/esploro/outputs/book/Futures-in-Education-Principles-practices-and-potential-monograph-No-5-the-strategic-foresightmonograph-series/9921857613901341

- Gidley, Jennifer. (2001). 'Education for All' or Education for Wisdom? Unfolding Learning Societies: Deepening the Dialogues. http://citeseerx.ist.psu.edu/viewdoc/download?doi=10.1.1.606.758\&rep=rep1\&type $=$ pdf

- Graham, M. A. (2007). Art, Ecology and Art Education: Locating Art Education in a Critical Place-based Pedagogy. Studies in Art Education, 48(4), 375-391. https://doi.org/10.1080/00393541.2007.11650115

- Gray, P. (2011). The decline of play and the rise of psychopathology in children and adolescents. American Journal of Play, 3(4), 443-463. https://eric.ed.gov/?id=EJ985541

- Gruenewald, D. A. (2003). The best of both worlds: A critical pedagogy of place. Educational Researcher, 32(4), 3-12. https://doi.org/10.3102/0013189X032004003

- Hardy, B. (1968, October). Towards a poetics of fiction: 3) An approach through narrative. In Novel: A forum on fiction (Vol. 2, No. 1, pp. 5-14). Duke University Press.

- Heft, H., \& Chawla, L. (2006). Children as agents in sustainable development: The ecology of competence. In Children and their environments: Learning, using and designing spaces. Cambridge University Press.

- Henderson, L. Kuříková, M., Kroufek, R. (2021). Syntéza kreativního učení a vzdělávání pro udržitelný rozvoj v České republice. Envigogika 16(2) (v recenzním procesu) https://doi.org/10.14712/18023061.628

- Henderson L., Kuř́ková, M. (2021). Kreativní vzdělávání pro udržitelnou budoucnost: metodické inspirace projektu Vzdělávání pro budoucnost. Praha, Centrum pro 
otázky životního prostředí. ISBN 978-80-87076-23-1. Dostupné online: https://www.czp.cuni.cz/knihovna/kreativ_vzdel.pdf

- Hopkins, R. (2019). From What Is to What If: Unleashing the power of imagination to create the future we want. Chelsea Green Publishing. ISBN: 978-1-60358-906-2

- Hooks, b. (1992). Black looks: Race and representation. South End Press Boston. ISBN: $978-1-315-74322-6$

- Inayatullah, S., \& Wildman, P. (1998). Futures studies: Methods, emerging issues, and civilisational visions. CD Rom. Brisbane (Australia): Prosperity Press.

- Inwood, H. J. (2008). At the crossroads: Situating place-based art education. Canadian journal of environmental education, 13(1), 29-41. https://eric.ed.gov/?id=EJ842767

- Kim, K. H. (2011). The creativity crisis: The decrease in creative thinking scores on the Torrance Tests of Creative Thinking. Creativity Research Journal, 23(4), 285295. https://doi.org/10.1080/10400419.2011.627805

- Lucas, B., Claxton, G., \& Spencer, E. (2014). Progression in student creativity in school: First steps towards new forms of formative assessments. Contemporary Readings in Law \& Social Justice, 6(2). https://www.oecd-ilibrary.org/education/progression-in-student-creativity-in-school_5k4dp59msdwk-en

- McDowell, L. (1999). Gender, identity and place: Understanding feminist geographies. U of Minnesota Press.

- McInerney, P., Smyth, J., \& Down, B. (2011). 'Coming to a place near you?' The politics and possibilities of a critical pedagogy of place-based education. Asia-Pacific Journal of Teacher Education, 39(1), 3-16. https://doi.org/10.1080/1359866X.2010.540894

- Mezirow, J. (2003). Transformative learning as discourse. Journal of transformative education, 1(1), 58-63. https://doi.org/10.1177/1541344603252172

- Okri, B. (1991). The Famished Road. London : Jonathan Cape.

- Percy-Smith, B., Burns, D. (2013). Exploring the role of children and young people as agents of change in sustainable community development. Local Environment, 18(3), 323-339. https://doi.org/10.1080/13549839.2012.729565

- Percy-Smith, B., \& Thomas, N. (2010). Emerging themes and new directions. Handbook of Children and Young People's Participation: Perspectives from Theory and Practice, 356-366.

- Plous, S. (1993). The psychology of judgment and decision making. Mcgraw-Hill Book Company.

- Ramos, J. (2005). Futures education as temporal conscientisation. Social Alternatives, 24(4), 25-31. https://search.informit.org/doi/epdf/10.3316/ielapa.200602815

- Rautins, C., \& Ibrahim, A. (2011). Wide-Awakeness: Toward a Critical Pedagogy of Imagination, Humanism, Agency, and Becoming. International Journal of Critical Pedagogy, 3, 24-36. http://www.partnershipsjournal.org/index.php/ijcp/article/view/247 
- Reed, B. (2007). Shifting from 'sustainability' to regeneration. Building Research \& Information, 35(6), 674-680. https://doi.org/10.1080/09613210701475753

- Shove, E. (2010). Social Theory and Climate Change. Theory, Culture \& Society, 27(2-3), 277-288. https://doi.org/10.1177/0263276410361498

- Silverstein, L. B., \& Layne, S. (2010). Defining Arts Integration. The John F. Kennedy Center for the Performing Arts. http://www.artsintegrationpd.org/wp-content/uploads/2017/07/What-is-Arts-Integration.pdf

- Silverstone, L. (1997). Art therapy: The person-centered way: Art and the development of the person. Jessica Kingsley Publishers.

- Smith, G. A. (2007). Place-based education: Breaking through the constraining regularities of public school. Environmental Education Research, 13(2), 189-207. https://doi.org/10.1080/13504620701285180

- Sobel, D. (2004). Place-based education: Connecting classrooms \& communities (p. 105). Orion Society.

- Sterling, S. (2010). Learning for resilience, or the resilient learner? Towards a necessary reconciliation in a paradigm of sustainable education. Environmental Education Research, 16(5-6), 511-528. https://doi.org/10.1080/13504622.2010.505427

- Theis, J. (2010). Children as active citizens: An agenda for children's civil rights and civic engagement. In A Handbook of Children and Young People's Participation. Routledge.

- Thomson, P., Hall, C., Sefton-Green, J., \& Jones, K. (2012). The Signature Pedagogies Project: Final Report. London: Creativity, Culture and Education.

- Twenge, J. M., Zhang, L., Im, C. (2004). It's beyond my control: A cross-temporal meta-analysis of increasing externality in locus of control, 1960-2002. Personality and social psychology review, 8(3), 308-319. https://doi.org/10.1207/s15327957pspr0803_5

- UNECE. (2011). Learning for the future: Competences in Education for Sustainable Development (Roč. 2011).ECE/CEP/AC.13/2011/6. https://www.unece.org/fileadmin/DAM/env/esd/6thMeetSC/Learning\%20for\%20the\%20Future \%20Competences $\% 20$ for $\% 20$ Educators $\% 20$ in $\% 20$ ESD/ECE CEP AC13 $20116 \% 20$ COMPETENCES\%20EN.pdf

- UNESCO (2019) What is Education for Sustainable Development? https://en.unesco.org/themes/education-sustainable-development/what-is-esd

- Vaish, A., Grossmann, T., \& Woodward, A. (2008). Not all emotions are created equal: The negativity bias in social-emotional development. Psychological Bulletin, 134(3), 383-403. https://doi.org/10.1037/0033-2909.134.3.383

- Van der Kolk, B. A. (2015). The body keeps the score: Brain, mind, and body in the healing of trauma. Penguin Books.

- Wagar, W. W. (2002). Past and future. Advancing Futures, 83-90.

- Wallen, R. (2012). Ecological art: a call for visionary intervention in a time of crisis. Leonardo, 45(3), 234-242. https://doi.org/10.1162/LEON a 00365 
- Weir, J. (2016). The Way the Light Hits a Web. Art Education, 69(3), 6-11. https://doi.org/10.1080/00043125.2016.1158568

- Yelland, N., \& Arvanitis, E. (2018). Transformative pedagogies in early childhood education. SAGE Publications Sage UK: London, England. https://journals.sagepub.com/doi/pdf/10.1177/1463949117734979

\section{Zdroje - organizace, inspirativní příklady a další čtení}

- Asociace futurologů Slovensko https://www.futurologia.sk/index.php?id=perspektivy

- Prognosticky ustav, SK, http://www.prog.sav.sk/

- Technologické centrum, Oddělení strategických studií (výhledové studie) https://www.tc.cz/cs/o-nas/oddeleni-strategickych-studii

- Asociace futurologů https://www.apf.org/

- Guerilla Futures https://c4aa.org/2017/11/webinar-querrilla-futures

- The reluctant Futuryst Blog https://futuryst.blogspot.com/

- Budoucnost ve vzdělávání https://www.academia.edu/197836/Futures in Education_Principles_Practices_and_Potential

- Aktivity ze Hry o budoucnost http://situationlab.org/wp-content/uploads/2015/10/FUTURETHING_Print-and-Play.pdf

- Databáze uvědomění si budoucnosti pro testování toho, jak budoucnost vnímají lidé https://futuresconsciousness.utu.fi/

- Transition Towns Network https://transitionnetwork.org/

- Re:imagining change, The Centre for Story-based Strategy https://drive.google.com/drive/u/0/folders/1ZupMkyi8RpnsuFpLicFm7iR1P8ArLHHc

- The Arthur C. Clarke Center for Human Imagination seeks to understand, enhance and enact the gift of human imagination by bringing together the inventive power of science and technology, with the critical analysis of the humanities, and the expressive insight of the arts. http://imagination.ucsd.edu/index.html

- The Center for Artistic Activism "helps people use their creativity and culture to effect power". Decolonizing our imaginations for the future is essential for imagining and effecting change.

- Institute of Imagination https://ioi.london/

- Future Day, annually March 1st http://www.future-day.org/ 